\title{
Impact Analysis of Mutual Rotation of Roller Bearing Rings on the Process of Contact Stresses in Rolling Elements
}

Lenka Jakubovičová, Milan Sága, Milan Vaško

Department of Applied Mechanics, Faculty of Mechanical Engineering, University of Žilina, Univerzitná 1, 01026 Žilina, Slovak Republic. \{lenka.jakubovicova, milan.saga, milan.vasko\}@fstroj.uniza.sk

Purpose of this paper is to present the magnitude of the impact of roller bearing rings mutual slewing to the process of contact stresses in rolling elements. The roller bearing satisfies prescribed basic static load rating if it is loaded by the maximum specified load only in the radial direction according to the ISO/TS 16281. However, the real roller bearings are not loaded only in the radial direction in practice. During operation there is mutual slewing of the bearing roller rings. This leads to a change in the conditions of contact and to a change in contact stresses. Stress state will be evaluated in the most loaded element of the roller bearing. Equivalent stress will evaluated according to the theory of HMH, stresses $P 1$ to $P 3$ at gradual slewing of the roller bearing rings, angle $\varphi$ from $0^{\prime}$ to $8^{\prime}$. For the analysis of this problem was used the finite-element program ADINA.

Keywords: computational analysis, stress analysis, roller bearing, Hertz contact stresses, ADINA

\section{Acknowledgements}

This work has been supported by VEGA grant No. 1/1089/11 and KEGA grant No. 004ŽU-4/2012.

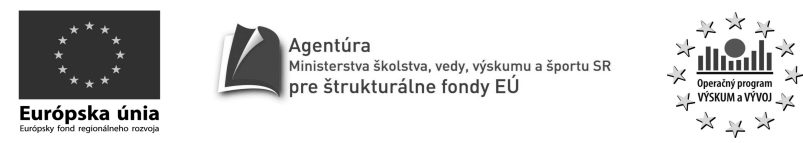

We support research activities in Slovakia / The project is co-financed by the European Union.

This contribution is the result of the project implementation: Development of optimum technology for the analysis of limit states of structural elements in contact, ITMS code 26220220118, supported by the Research \& Development Operational Programme funded by the ERDF.

\section{References}

[1] BATHE, K. J. (1982). Finite Element Procedures. New Jersey, Prentice Hall, 1982. ISBN 0-13-301456-4.

[2] HILLS, D. A., NOWELL, D. AND SACKFIELD, A. (1993). Mechanics of Elastic Contacts. Butterworth \& Heinemann, Oxford. ISBN 0-7506-0540-5.

[3] JAEGER, J. (2005). New Solutions in Contact Mechanics. WIT Press, Southampton, Boston. ISBN 1-85312994-1.

[4] JAKUBOVIČOVÁ, L., VAŠKO, M., KOMPIŠ, V. (2003). Trefftz Functions Using the Fundamental Solution with the Singularity Outside the Domain. In Computer Assisted Mechanics and Engineering Sciences. 2003, Vol. 10, No. 4, p. 515-521. ISSN 1232-308X.

[5] JOHNSON, K. L. (1985). Contacts Mechanics. Cambridge University Press, Cambridge. ISBN 0-521-25576-7.

[6] KRYNKE, M., SELEJDAK, J., BORKOWSKI, S. (2012). Diagnosis and Damage of Bearings. In Manufacturing Technology. 2012, Vol. 12, No. 13, p. 140-144. ISSN 1213-2489.

[7] NOVÝ, F., ČINČALA, M., KOPAS, P., BOKŮVKA, O. (2007). Mechanisms of High-strength Structural Materials Fatigue Failure in Ultra-wide Life Region. In Materials Science and Engineering A. 2007, Vol. 462, No. 1-2, pp. 189-192. ISSN 0921-5093.

[8] SÁGA, M., VAŠKO, M. (2009). Stress Sensitivity Analysis of the Beam and Shell Finite Elements. In Communications. 2009, Vol. 11, No. 2, pp. 5-12. ISSN 1335-4205.

[9] SAPIETOVÁ, A., SÁGA, M., NOVÁK, P. (2012). Multi-software Platform for Solving of Multibody Systems Synthesis. In Communications. 2012, Vol. 14, No. 3, pp. 43-48. ISSN 1335-4205.

[10] SLÁDEK, A., FABIAN, P., PASTIRČÁK, R., BREZNIČAN, M. (2012). The Roundness and Microstructure of Thin-wall Bearing Rings. In Manufacturing Technology. 2012, Vol. 12, No. 13, p. 237-241. ISSN 1213-2489.

[11] VAŠKO, A. (2007). Image Analysis in Materials Engineering. In: Konferencje, Poland. 2007, No. 61, pp. 667- 
670. ISSN 1234-9895.

[12] ŽMINDÁK, M., RIECKY, D. (2012). Meshless Modelling of Laminate Mindlin Plates under Dynamic Loads. In Communications. 2012, Vol. 14, No. 3, pp. 24-31. ISSN 1335-4205.

[13] British/International Standard BS ISO/281 (2007). Rolling bearings - Dynamic load ratings and rating life.

[14] Technical specification ISO/TS 16281 (2008). Rolling bearings - Methods for calculating the modified reference rating life for universally loaded bearings.

[15] http://www.tribology-abc.com/calculators/e2_3.htm 